\title{
Taxonomy of Entrepreneurial Activity
}

\section{Mr. Daniel Michael Ferguson, Purdue University, West Lafayette}

Daniel M. Ferguson is a graduate student in the Engineering Education Program at Purdue University and the recipient of NSF awards for research in engineering education. Prior to coming to Purdue he was Assistant Professor of Entrepreneurship at Ohio Northern University. Before assuming that position he was Associate Director of the Inter-professional Studies Program and Senior Lecturer at Illinois Institute of Technology and involved in research in service learning, assessment processes and interventions aimed at improving learning objective attainment. Prior to his University assignments he was the Founder and CEO of The EDI Group, Ltd. and The EDI Group Canada, Ltd, independent professional services companies specializing in B2B electronic commerce and electronic data interchange. The EDI Group companies conducted syndicated market research, offered educational seminars and conferences and published The Journal of Electronic Commerce. He was also a Vice President at the First National Bank of Chicago, where he founded and managed the bank's market leading professional Cash Management Consulting Group, initiated the bank's non credit service product management organization and profit center profitability programs and was instrumental in the breakthrough EDI/EFT payment system implemented by General Motors. Mr. Ferguson is a graduate of the University of Notre Dame and Stanford University.

\section{Dr. Sridhar S. Condoor, Saint Louis University, Parks College of Eng.}




\title{
A Taxonomy of Entrepreneurship
}

\begin{abstract}
The purpose of this paper is to propose a way of naming and categorizing entrepreneurial activities or entrepreneurship endeavors and events that clearly and succinctly differentiate one type of entrepreneurial activity or entrepreneurship event from another. Today in the popular press and academic literature there are overlapping definitions and terms that make it difficult for even an experienced observer or researcher to be certain of how to classify, describe and compare entrepreneurial endeavors. This paper discusses the definitions used to describe entrepreneurial activity which are often confusing and conflicting. It proposes an organization and categorization of entrepreneurial activity or taxonomy of entrepreneurship. Our categorization proposal differentiates entrepreneurial ventures in which the changes in products, processes or concepts occur based upon: 1. the significance of changes within their paradigm, 2. the venture's profit or non-profit status legal status, and 3. the types of leadership/management roles individuals assume in the entrepreneurial venture ${ }^{1}$. We believe the categorization scheme we propose will simplify the explanations and descriptions of entrepreneurial activity and lead to more useful analysis and comparisons of entrepreneurial outcomes.
\end{abstract}




\section{Introduction}

Among entrepreneurship scholars and researchers, a definitional debate over the terms "entrepreneur" and "entrepreneurship" exists and is a longstanding point of confusion. In 1991 Bygrave offered this comment: "scholars have been unable to agree on a definition of an "entrepreneur" in the 75 years or thereabouts since Schumpeter produced his seminal work on entrepreneurs ${ }^{2}$. " Sharma claims there are two divergent camps of entrepreneurship scholars: scholars who focus on the entrepreneur as a person with particular traits and skills and who carry out a process, and scholars who focus on the organization that entrepreneurs create. Sharma also asserts that Gartner and Bygrave define "'Entrepreneurship is [as] the creation of organizations" while Sharma notes the scholars from the other camp, for example Schumpeter, define " an entrepreneur [as] a person who carries out new combinations, which may take the form of new products, processes, markets, organizational forms, or sources of supply ${ }^{3}$." Addressing the abundant, confusing and overlapping definitions associated with entrepreneurial activity and the terms used to describe it is the goal of this paper. The taxonomy of entrepreneurship that we propose is intended to serve as an organizing map that clearly and distinctly classifies and differentiates types of engineering entrepreneurial activity by their change magnitude, organization location, the role of individuals leading the change and the nature of the change. This classification is critical for a field of engineering entrepreneurship as it helps to effectively communicate and analyze entrepreneurial activity in the engineering discipline by the researchers.

Our approach uses the categorization process to classify the entrepreneurial activity by answering these four questions: 
1. Nature and magnitude of change - What magnitude of change - an incremental innovation or a paradigm shift (due to product/venture/entrepreneur? - not clear with out something else. So added some suggestions)? (incremental or significant)

2. Responsibility - What type of organization is responsible for the change or paradigm shift? (profit or non-profit)

3. Role - What is the role of the individual is leading the change? (entrepreneur, small business owner/operator, self-employed, intrapreneur)

4. Type of change - What type of change is being proposed or implemented? (product, process, concept)

This classification scheme includes all types of entrepreneurial activity, not just the new Google's or EBay's of the popularized technology entrepreneurial space. While developing the classification scheme, we were conscious of of the entrepreneurial activity that occurred inside Apple that produced the iPhone and iPad and our classification scheme recognizes that this entrepreneurial activity as legitimate as it recognizes entrepreneurial activity occurring inside Goodwill, the Red Cross or a city's police and fire services if those organizations are behaving in an entrepreneurial way.

\section{Confusion about the definition of an entrepreneur and of entrepreneurship}

An entrepreneur is key to the economic well-being of societies according to Nobel Prize winner Robert Solow who established innovation (that is, entrepreneurial activity in organizations) as the cornerstone of economic growth. "This juxtaposition of plain speak and econometrics (defines) entrepreneurs (as people who) see a need and innovate, resulting in

improved economic well-being ${ }^{4} . "$ The debate on what makes one an entrepreneur has been 
going on for a couple of centuries and this is a key reason why a classification scheme for entrepreneurial activity is needed. Carland credits Schumpeter who credits Mill for using the term entrepreneur in economics literature in $1848^{5}$ and Tam credits Drucker who credits Say who defines the entrepreneur in 1800 as follows:

"The entrepreneur", said the French economist J. B. Say around 1800, "shifts economic resources out of an area of lower and into an area of higher productivity and greater yield ${ }^{6} . "$

This insight, "the shifting of resources from an area of lower yield to an area of higher yield", is important for our classification scheme, because this means our classification schema should acknowledge all the types of resource shifting that are occurring in our economy; e.g., new Starbucks, new truck drivers, new consultants, new products, or new ideas; all of which are examples of different types of resource shifting to obtain better yields.

Among entrepreneurship scholars and researchers, however, the definitional debate over entrepreneurship remains an open issue. In 1991 Bygrave offered his definitions of an entrepreneurial event, the entrepreneurial process and an entrepreneur: ${ }^{2}$

- $\quad$ An Entrepreneurial Event involves the creation of a new organization to pursue an opportunity.

- The Entrepreneurial Process involves all the functions, activities, and actions associated with the perceiving of opportunities and the creation of organizations to pursue them.

- An Entrepreneur is someone who perceives an opportunity and creates an organization to pursue it" 2 . 


\section{Confusion over entrepreneurship definitions among scholars}

Sharma, however, places Bygrave's definition of entrepreneurship in one of two divergent camps of entrepreneurship scholars:

1. Scholars focused on the entrepreneur as a person with certain traits and skills and carries out a process, and

2. Scholars focused on the organization that entrepreneurs create.

Sharma claims that Gartner and Bygrave define "'Entrepreneurship is [as] the creation of organizations" (Sharma, 1999) while Sharma notes the scholars from the other camp, for example Schumpeter, define "an entrepreneur [as] a person who carries out new combinations, which may take the form of new products, processes, markets, organizational forms, or sources of supply." Entrepreneurship according to Sharma is then "the process of carrying out new combinations" ${ }^{3}$.

This scholarly confusion has been addressed in two ways that are bringing order to entrepreneurial research. First Shane and Venkataraman define the field of entrepreneurship (research) as follows: "The field of entrepreneurship (research) is the scholarly examination of how, by whom, and with what effects opportunities to create future goods and services are discovered, evaluated and exploited" 7 .

Shane and Venkataraman's definition of entrepreneurship has now seeped into over 4,000 scholarly dissertations and journal articles. Second, Michael Morris, the Dean of the first ever College of Entrepreneurship at Oklahoma State University, defined a framework for 
entrepreneurial research that involves the entrepreneurial context, process, person, concept, resources and environment ${ }^{8}$ as shown in Figure 1. The 12 numbered categories as shown in boxes and ellipses in Figure 1 encompass all types of activity subject to entrepreneurial research and was essentially an inspiration for the design of our classification scheme. Yet another entrepreneurship definition is offered Bruce Barringer, the co-author of a popular entrepreneurship textbook, who says "entrepreneurship is a process" ${ }^{9}$. Today there are many labels for types of entrepreneurship with organizations like the Kaufman Foundation periodically promoting new flavors of entrepreneurship like "Icehouse Entrepreneurship".

Figure 1: Morris Framework of the Entrepreneurial Research Space

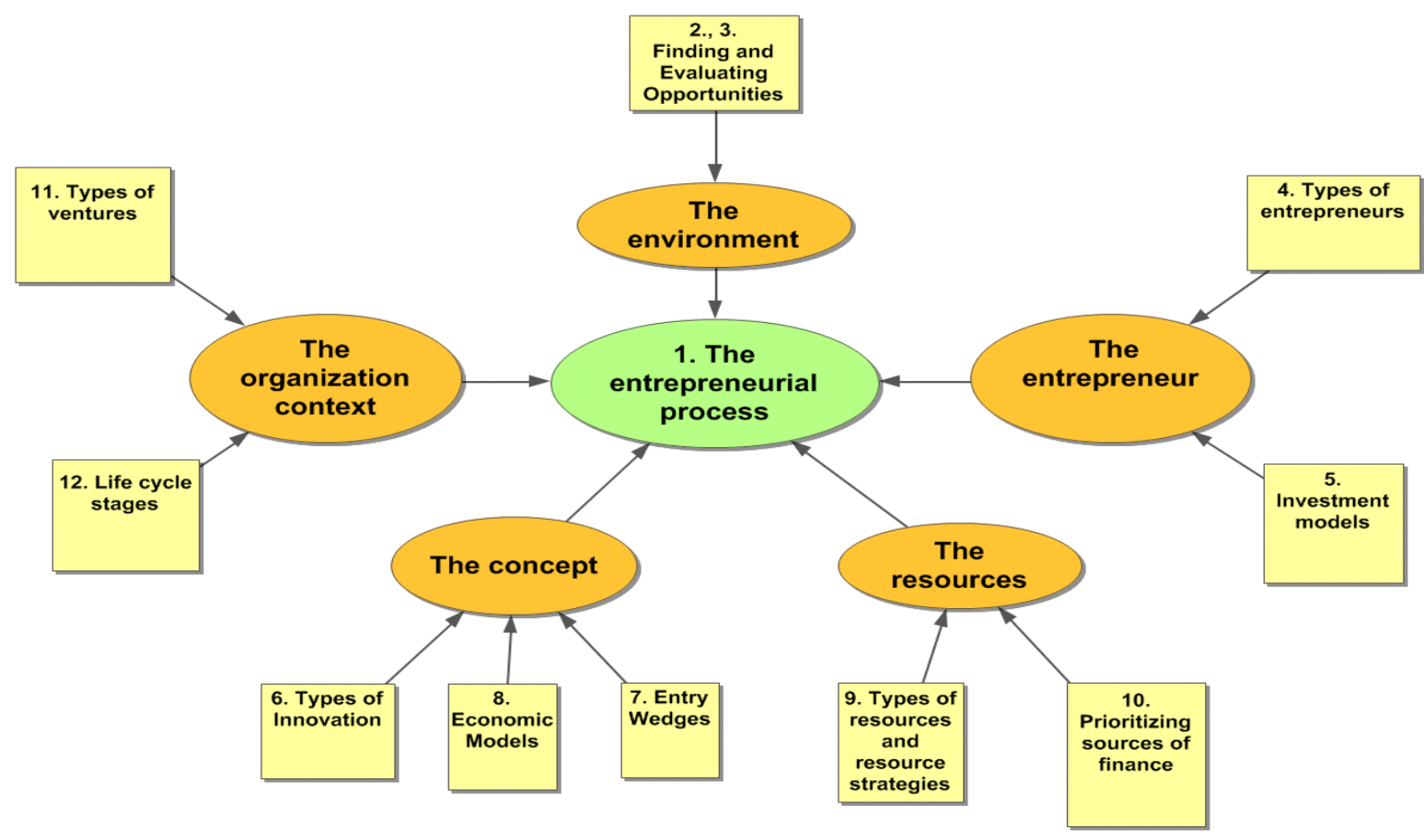


We believe a classification scheme must encompass relevant entrepreneurial organizations, the people who create and run these organizations, the purpose for which they are or were created and the nature of the products and services the entrepreneurial organizations provide to their end users and how all these pieces of the entrepreneurial puzzle tie together.

A summary of common definitions related to entrepreneurial activity is shown in table 1 below:

Table 1: Examples of entrepreneurial activity definitions

\begin{tabular}{|c|c|}
\hline Quote & Author \\
\hline $\begin{array}{l}\text { "The entrepreneur", said the French economist J. B. Say around 1800, "shifts } \\
\text { economic resources out of an area of lower and into an area of higher } \\
\text { productivity and greater yield." }\end{array}$ & $\operatorname{Tam}^{6}$ \\
\hline $\begin{array}{l}\text { "This juxtaposition of plain speak and econometrics (defines) entrepreneurs (as } \\
\text { people who) see a need and innovate, resulting in improved economic well- } \\
\text { being." }\end{array}$ & Robert Solow ${ }^{4}$ \\
\hline "Entrepreneurship is the creation of organizations." & Sharma ${ }^{3}$ \\
\hline $\begin{array}{l}\text { "An entrepreneur is a person who carries out new combinations, which may take } \\
\text { the form of new products, processes, markets, organizational forms, or sources } \\
\text { of supply." }\end{array}$ & Schumpeter \\
\hline $\begin{array}{l}\text { "Entrepreneurship_encompasses acts of organizational creation, renewal, or } \\
\text { innovation that occur within or outside existing organizations." }\end{array}$ & Sharma ${ }^{3}$ \\
\hline $\begin{array}{l}\text { "Entrepreneurs are individuals, acting independently or as part of a corporate } \\
\text { system, who create new organizations or instigate renewal or innovation within } \\
\text { existing organizations." }\end{array}$ & Sharma ${ }^{3}$ \\
\hline $\begin{array}{l}\text { "The field of entrepreneurship is the scholarly examination of how, by whom, } \\
\text { and with what effects opportunities to create future goods and services are } \\
\text { discovered, evaluated and exploited." }\end{array}$ & $\begin{array}{c}\text { Shane \& } \\
\text { Venkataraman }^{7}\end{array}$ \\
\hline $\begin{array}{l}\text { "Entrepreneurial thinking (in a corporate context)"[ is] "creating a competitive } \\
\text { advantage through entrepreneurship." }\end{array}$ & Kuratko etal. ${ }^{10}$ \\
\hline $\begin{array}{l}\text { "The entrepreneurial mindset_(is) the ability to rapidly sense, act, and mobilize } \\
\text { (resources), even under uncertain conditions." }\end{array}$ & Haynie etal. ${ }^{11}$. \\
\hline $\begin{array}{l}\text { "Entrepreneurial thinking is a specific group of competencies relevant to the } \\
\text { exercise of successful entrepreneurship." }\end{array}$ & Kenney etal. ${ }^{12}$ \\
\hline $\begin{array}{l}\text { "The framework of entrepreneurship involves the entrepreneurial context, } \\
\text { process, person, concept, resources and environment." }\end{array}$ & Morris $^{8}$ \\
\hline "Entrepreneurship is a process." & $\begin{array}{l}\text { Barringer \& } \\
\text { Ireland } 9\end{array}$ \\
\hline
\end{tabular}




\section{Need for a Taxonomy of Entrepreneurship}

Providing a conceptual tool or classification scheme for sorting out the abundant, confusing and overlapping definitions associated with entrepreneurial activity as illustrated in Table 1 is the purpose of this paper. We believe that a consensus classification scheme is needed for collating and comparing all the research, economic investment and legal and regulatory frameworks that are purported to support entrepreneurial activity. U.S. political and business leaders also believe that entrepreneurial activity is critical to the well-being of society as economic research has established that entrepreneurial activity is the primary creator of new jobs. Therefore, common agreement on how to define, describe and measure entrepreneurial activity is in our minds critically important.

In this paper therefore the following definitions of entrepreneur, entrepreneurship and entrepreneurial behavior are used:

- Entrepreneur: "Entrepreneurs are individuals, acting independently (an entrepreneur) or as part of a corporate system (an Intrapreneur), who create new organizations or instigate renewal or innovation (in products, processes or concepts) within existing organizations" ${ }^{\prime 3}$. In our schema a person who behaves in this manner can be acting independently as a self-employed person, a small business owner or an 'independent' entrepreneur and they can be working on incremental change or 'big' paradigm shifts.

- Entrepreneurship or the Entrepreneurial Process is : "all the functions, activities, and actions associated with (people) perceiving opportunities and the creation [or modifications] of organizations or processes to pursue (those social or economic 
opportunities)" ${ }^{2}$. Entrepreneurship in our classification scheme can then involve big or incremental changes, occur inside for profit or nor-for-profit organizations, or be practiced by the self-employed, small business owners, intrapreneurs or the Schumpeter 'creative destroyer' independent entrepreneurs.

- Entrepreneurial behavior is: the cognitive ability to see opportunities to fill socioeconomic needs and the ability and willingness to act on those perceptions ${ }^{3,4,10,11}$. This entrepreneurial behavior is what entrepreneurs, the small business owner, the selfemployed or the intrapreneur do when they act entrepreneurially, i.e., create new organizations or instigate renewal or innovation (in products, processes or concepts) within existing organizations.

\section{Proposed Taxonomy of Entrepreneurship}

The classification scheme that we propose is first based upon the nature and magnitude of the change that is occurring; the second branching in our schema is the organization's societal strategy in which the changes occur; the third level of differentiation is the types of individuals involved or roles those individuals play in the change that is occurring, and fourth whether the change involves a new product, process or concept ${ }^{1}$. The type of change occurring, a paradigm shift (big change) or incremental change is one of the hardest classification conditions to apply because it is often a subjective judgment as to the real nature or eventual impact of a process change. For example, small or incremental improvements to a paradigm or a new way of doing business are the life blood of normal engineering and businesses practices. However we account for both significant change which we label in figure 2, paradigm shifts, and incremental changes, which we label in figure 3, no paradigm shift. 
An organization's- for-profit and non-profit status is the second classification level in our schema and this classification calls attention a significant overlooked area of entrepreneurial activity, the not-for-profit sector of our economy. Examples of significant not-for-profit organizations with potential entrepreneurial activity are for example: the TEA party, MADD, the Red Cross, or the Boy or Girl Scouts. Figure 3 below shows a similar image to Figure 2 except it displays the proposed classification schema focused on incremental change or as we name it no paradigm shift.

Figure 2 Taxonomy of Entrepreneurship- Paradigm Shift

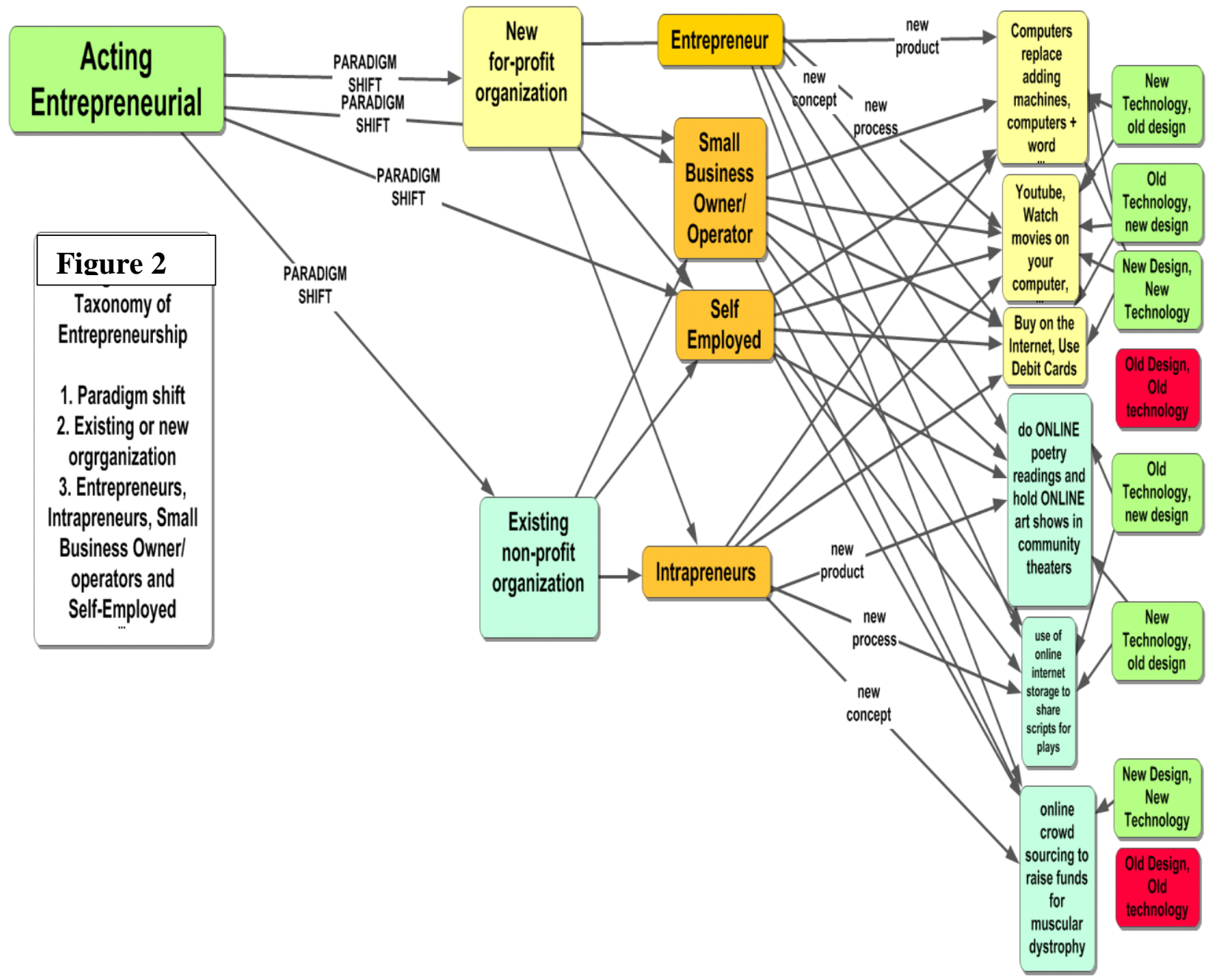


Figure 3 Taxonomy of Entrepreneurship-No Paradigm Shift

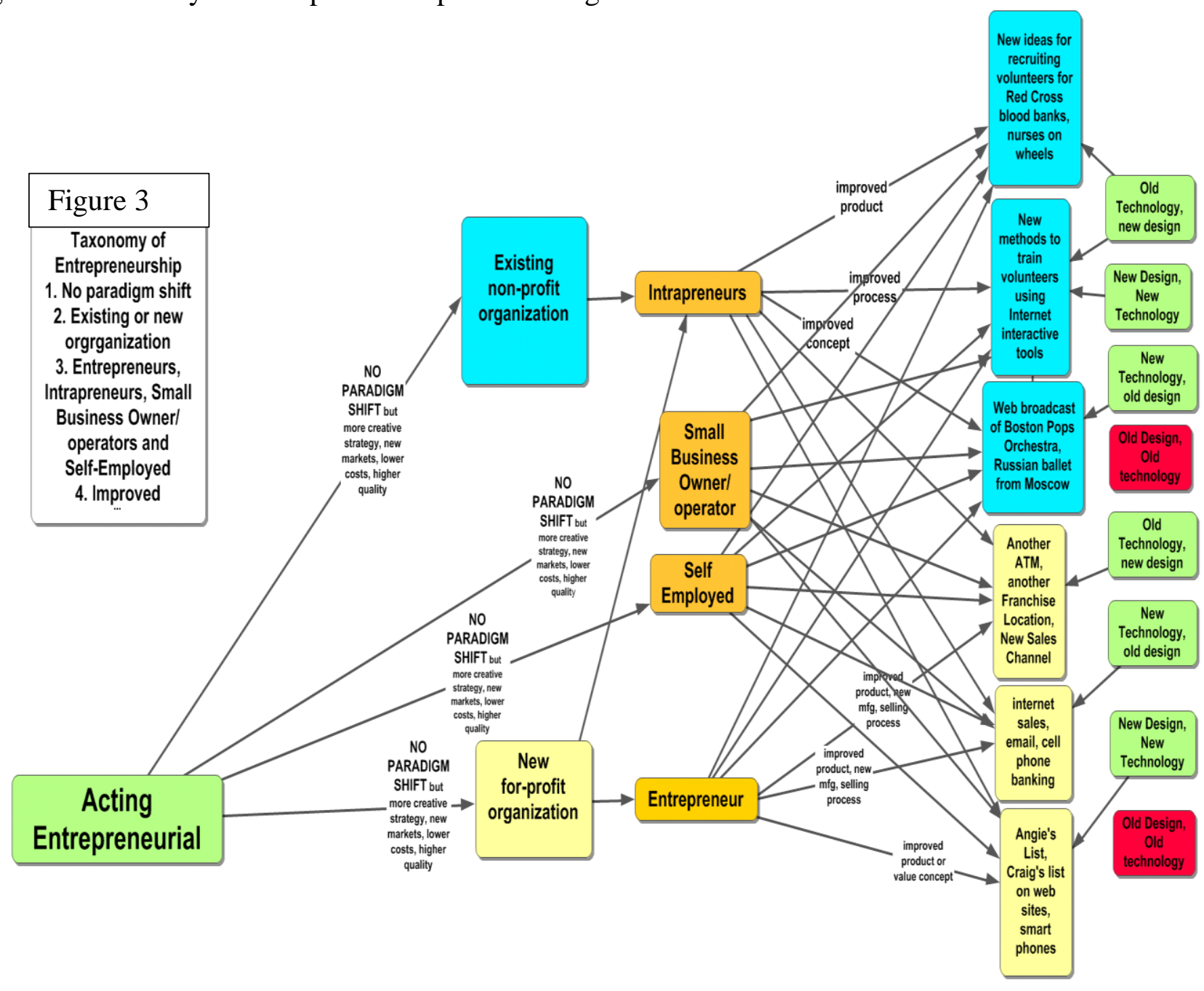

In the third classification level in both figures 2 and 3 , the individual driving the change is identified and includes small business managers and self-employed craftsmen and professionals as well as entrepreneurs working inside large companies-intrapreneurs-a role defined as intrapreneurship ${ }^{13}$ or fourth, the Schumpeter creative destroyer entrepreneur. The next two levels in the figure 2 and 3 diagrams are provided to give examples of how our classification schema classifies many different types of entrepreneurial activity. The first of these descriptive additions breaks out examples by whether they relate to new products, new processes or new concepts and then examples are listed for each of these three categories by whether they are 
combinations or new or old designs or old or new technologies. The last of these two explanatory levels identifies paired combinations of old and new designs and old and new technologies. Only old designs and old technologies-like daily newspapers or postcards are not connected to the diagram as they do not represent change. The purpose of the last or right-most description addition to the diagrams and the named examples is simply to indicate how entrepreneurial activities do not have to involve only new technology but can be old technologies used in new design ways-which actually in part explains the recent success of Pinterest or Youtube. This set of examples depicting the combinations of old or new design and old or new technologies we believe is further evidence of the efficacy of our classification scheme-it captures or includes all of the types of entrepreneurial activity of which we are aware. Table 2 below is a summary of our classification scheme in tabular format.

Table 2 Taxonomy Structure

\begin{tabular}{|c|c|c|}
\hline Organization types & For profit & Non Profit \\
\hline Forces driving change & $\begin{array}{l}\text { Big change in paradigm } \\
\text { Incremental Change in process }\end{array}$ & $\begin{array}{l}\text { Big change in paradigm } \\
\text { Incremental change process }\end{array}$ \\
\hline $\begin{array}{l}\text { Two contexts where change } \\
\text { occurs }\end{array}$ & $\begin{array}{l}\text { New organization } \\
\text { Existing organization }\end{array}$ & $\begin{array}{l}\text { New organization } \\
\text { Existing organization }\end{array}$ \\
\hline $\begin{array}{l}\text { Types of individuals driving } \\
\text { change }\end{array}$ & $\begin{array}{l}\text { Small business manager } \\
\text { Self-employed } \\
\text { Intrapreneur } \\
\text { Entrepreneur }\end{array}$ & $\begin{array}{l}\text { Small business manager } \\
\text { Self-employed } \\
\text { Intrapreneur, } \\
\text { Entrepreneur }\end{array}$ \\
\hline Changes occurring in & $\begin{array}{l}\text { Product } \\
\text { Process } \\
\text { Concept }\end{array}$ & $\begin{array}{l}\text { Product } \\
\text { Process } \\
\text { Concept }\end{array}$ \\
\hline \multirow{2}{*}{$\begin{array}{l}\text { Types of change/paradigm } \\
\text { shift because of mixing of old } \\
\text { and new designs and } \\
\text { technologies }\end{array}$} & $\begin{array}{l}\text { old process/product/concept } \\
\text { design, old technology }\end{array}$ & $\begin{array}{l}\text { old process/product/concept } \\
\text { design, old technology }\end{array}$ \\
\hline & $\begin{array}{l}\text { new process/product/concept } \\
\text { design, new technology }\end{array}$ & $\begin{array}{l}\text { new process/product/concept } \\
\text { design, new technology }\end{array}$ \\
\hline
\end{tabular}




\section{The background for our classification scheme}

\section{Paradigm shifts}

Significant change in paradigms however is the most difficult and challenging task for entrepreneurial activity and not always the most rewarding. According to Kiesling, Schumpeter says "there is a cost to economic progress; a necessary complement of' the great economic and social process by which businesses, individual positions, forms of life, cultural values and ideals, sink in the social scale and finally disappear" and Kiesling further adds that Schumpeter terms this replacement of old structures with new structures as the process of "creative destruction" ${ }^{14}$.

The issue of types of paradigm shifts or the forces causing or leveraging minor or major paradigm shifts and the different ways paradigm shifts are greeted or deployed has also been extensively covered in literature. Peter Drucker in his book, Innovation and Entrepreneurship, identified seven social, economic, and technological sources of paradigm shifts which drive: economic, social, and technological change ${ }^{15}$.

Table 3: Drucker's Seven Paradigm Shift Forces

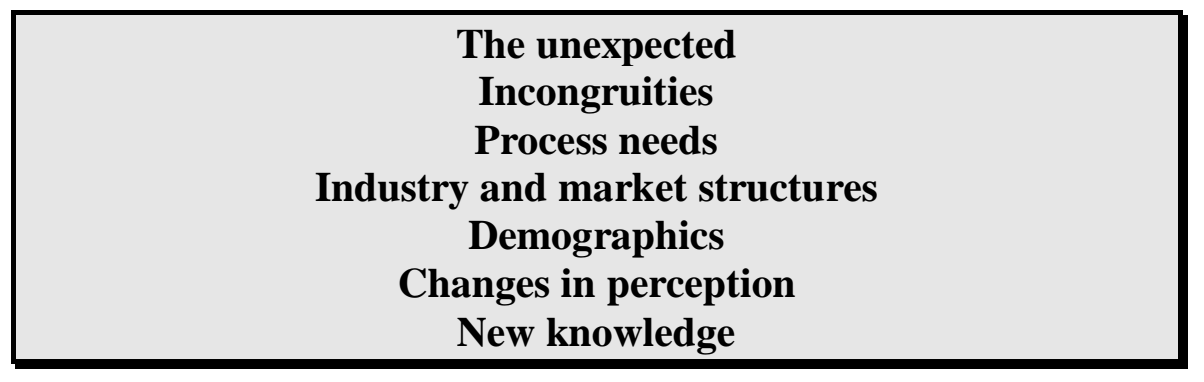

Paradigm shifts can also morph into a different implementation in different contexts or cultures. In particular how academic, corporate, governments or countries implement new security protocols for online access to the Internet we believe has as much to do with the culture of their organization as it does with any changes in the current paradigm. 


\section{Intrapreneurs, Small Business Owner/managers, and the Self-Employed}

When discussions about entrepreneurship are held it often true, in our experience, the largest numbers of entrepreneurs-intrapreneurs or the small business manager or self-employedare overlooked or not given much attention. However the proposed scheme treats all individuals functioning entrepreneurially as valid subjects for being classified. The largest number of entrepreneurs in the U.S. in our classification scheme is the small business owner/operator and the self-employed. This segment of entrepreneurs Carland argues is differentiated from the Cantillion-Say entrepreneur type because they are not usually creating a significant paradigm shift ${ }^{5}$. Many of their innovations are geographic innovations, e.g., adding a gas station or coffee houses in their town. Similar small business examples are 7-11 stores, beauty parlors, McDonald's restaurants, or car washes. Examples of the self-employed are plumbers, hunting guides, writers, painters, artists, independent truck drivers (there are 389,000 independent truck drivers in the U.S. with their own rigs) ${ }^{16}$, consultants, or adjunct professors. There are even professional and licensed versions of the small business owner/operator and self-employed such as doctors, dentists, surveyors, lawyers, accountants, or real estate appraisers. Davies argues that newness as in a new location or a new value product or process proposition is actually a critical feature of any marketing strategy. The value of a convenient location is obvious-if you live and work in in a small town and you don't want to travel 70 miles for your product or service ${ }^{17}$.

Carland provided 1977 small business data in his 1984 journal article which we have updated in Table 3 to 2007-08 numbers provided from the 2010 census database. Small firms or one person no-employee businesses represent the greatest proportion of our total entrepreneurs at 
94.1\%. Small businesses are started and run by two particular types of entrepreneurs, the small business owner-operator and the self-employed/no-employees entrepreneur ${ }^{5}$. Overall in the U.S. in 2007 we had 28.95 million businesses of which 21.35 million were self-employed and 5.9 million were organizations with more than 1 but less than 200 employees. These types of small or smaller businesses are critically important to our economy because they create a significant share of the new jobs in our economy, as much as $50 \%$ by some estimates. As shown in Table 3 small businesses accounted for 39\% of our GNP and 57\% of our total employment in 2007-2008.

Table 3 Data on Small Business and Self-Employed Entrepreneurs

\begin{tabular}{|c|c|c|c|c|c|}
\hline \multirow{2}{*}{ Category } & \multicolumn{2}{|c|}{ Carland's 1977 Data } & \multicolumn{2}{c|}{ Current 2007-08 Economic Data } & $\begin{array}{c}\text { Current 2007-08 } \\
\text { Economic Census Data }\end{array}$ \\
\cline { 2 - 6 } & $\begin{array}{c}\text { Total Small } \\
\text { businesses }\end{array}$ & $\begin{array}{c}\text { Total all } \\
\text { Businesses }\end{array}$ & Small businesses & Self employed & $\begin{array}{c}\text { Total all non-farm } \\
\text { Businesses }\end{array}$ \\
\hline $\begin{array}{c}\text { Number of } \\
\text { businesses }\end{array}$ & 14.7 million & & $5,930,132$ & $21,351,320$ & $28,952,489$ \\
\hline $\begin{array}{c}\% \text { all } \\
\text { businesses }\end{array}$ & $99.7 \%$ & $44 \%$ & $20.5 \%$ & $73.7 \%$ & $95.9 \%$ \\
\hline $\begin{array}{c}\text { Small Business } \\
\% \text { of GNP }\end{array}$ & & $47 \%$ & & & $39 \%$ \\
\hline $\begin{array}{c}\text { Small Business } \\
\% \text { of Business } \\
\text { Employment }\end{array}$ & & & & $57.3 \%$ \\
\hline
\end{tabular}

However, as Carland also points out these types of small businesses are cohesive or homogenous examples of new business generation (one more Starbucks) and are not the kind of entrepreneurial organizations that Schumpeter and other economists of the Austrian school labeled in 1934 fomenting 'creative destruction' ${ }^{5}$. Those creative destroyers according to Carland also make up only a small proportion of the small business numbers pie ${ }^{5}$ and only $6.3 \%$ of all non-farm employees ${ }^{18}$ although researchers contend that they account for a significant share of total of job creation. ${ }^{19,20}$ Examples of creative destroyers who started as small businesses in our time include McDonalds, Wendys, or Netflix and Redbox who contributed to 
the demise of Blockbuster; Amazon which hastened the demise of Borders; or Skype or Vonage which contributed to the dissolution of Old (long distance) AT\&T. Other less obvious creative destruction paradigm shifts are occurring with the new social media paradigms accentuated by Twitter and Facebook which both started as small businesses and are impacting the USPS and phone companies and similar innovations and paradigm shifts are also occurring in healthcare ${ }^{21,22}$.

\section{Intrapreneurs}

An intrapreneur is an individual within an existing organization who contributes to innovations that result in new or improved products, processes or concepts, e.g., many employees of Apple, SalesForce.com, Ebay, Amazon, or Nike are intrapreneurs. These intrapreneurial contributions are also critically important to our economy and their importance for public companies is captured by revenue gains, stock prices and other economic events. Measuring the number and importance of intrapreneurs is problematic, however, as the individuals who are involved in product development within small and large organizations are buried in the employment numbers and economic results reported by those companies. Furthermore intrapreneurs are often part of a team of people and resources which are deployed by organizations to create positive changes directed toward achieving the goals of the organization. So we know intrapreneurs exist, number probably in the millions and are critical to entrepreneurship within existing enterprises of any size. 


\section{Conclusions and Future Steps}

Figures 2 and 3 depict the application of our proposed classification scheme to different types of entrepreneurs and entrepreneurially activity of which we are aware. In particular, the data on small businesses and the self-employed shows millions of people behaving entrepreneurially in our economy. To order, measure, research, account and report on this vast enterprise in a logical manner prompted us to develop the classification scheme and write this paper to stimulate the discussion and debate about an all-encompassing schema that captures all entrepreneurial activity. In our opinion intrapreneurs, acting entrepreneurially, or the selfemployed or small business owner/operators acting entrepreneurially all need to be called entrepreneurs along with their more famous brethren, the founders of Google, Facebook, Twitter, etc. They are all taking risks, fomenting change through the reallocation of resources, bringing new designs or new technology to bear on markets and users whether motivated by profit or social good.

The next steps are to engage our communities in a discussion or debate on the classification scheme and to discuss and debate the examples presented. We intend by our scheme to increase the recognition as entrepreneurs to intrapreneurs, to the self-employed professional and finally to the small business owner /operator, all of whom are critical to creating jobs in our economy. 


\section{References}

1 Miller, D. The Correlates of Entrepreneurship in Three Types of Firms. Management Science 29 (1983).

2 Bygrave, W. D. \& Hofer, C. W. Theorizing about Entrepreneurship. Entrepreneurship: Theory \& Practice 16, 13-22 (1991).

3 Sharma, P. Toward a Reconciliation of the Definitional Issues in the Field of Corporate Entrepreneurship. Entrepreneurship: Theory \& Practice 23, 11-27 (1999).

4 Mann, C. L. Kauffman Thoughtbook. (The Kaufman Foundation fro Entrepreneurship, Kansas City, MO, 2007).

5 Carland, J. W. H. Differentiating Entrepreneurs from Small Business Owners: A Conceptualization. Academy of Management Review 9, 354-359 (1984).

6 Tam, H. How and to what extent does entrepreneurship education make students more entrepreneurial? A California case of the Technology Management Program PhD thesis, University of California, Santa Barbara, (2009).

7 Shane, S. \& Venkataraman, S. The Promise of Entrepreneurship as a Field of Research. The Academy of Management Review 25, 217-226 (2000).

$8 \quad$ Morris, M. in The Experiential Classroom X. (Oklahoma State University).

9 Barringer, B. R. \& Ireland, R. D. Entrepreneurship: Successfully Launching New Ventures. Vol. 2nd Edition (Pearson/ Prentice Hall, 2008).

10 Kuratko, D. F., Hornsby, J. S., Naffziger, D. W. \& ;Montagno, R. V. Implementing entrepreneurial thinking in established organizations. Advanced Management Journal 58 (1993).

11 Haynie, J. M., Shepherd, D., Mosakowski, E. \& Earley, P. C. A situated metacognitive model of the entrepreneurial mindset. Journal of Business Venturing 25, 217-229 (2010).

12 Mitchelmore, S. \& Rowley, J. Entrepreneurial Competencies: a literature review and development agenda. International Journal of Entrepreneurial Behavior and Research 16 (2010).

13 Kenney, M. \& Mujtaba, B. Understanding Corporate Entrepreneurship and Development: A Practitioners View of Organizational Intrapreneurship. Journal of Apllied Management and Entreprenurship 12 (2007).

14 Kiessling, T. S. Entrepreneurship and Innovation: Austrian School of Economics to Schumpeter to Drucker to Now. Journal of Applied Management and Entrepreneurship 9 ( 2004).

15 Drucker, P. F. Innovation and Entrepreneurship: Practice and Principles. (Harper Business, 1986).

16 Trucking.net. (Trucking.net, 2012).

17 Davies, G. Positioning, image and the marketing of multiple retailers. International Review of Retail, Distribution \& Consumer Research 2, 13 (1992).

18 Government, U. S. F. (ed Census Bureau) (Washington D.C., 2007).

19 Yochelson, J. The Talent Imperative:Meeting America's challenge in Science and engineering ASAP. 13 (Building Engineering and Science Talent, San Diego, CA, 2002).

20 National Academy of Sciences, National Academy of Engineering \& Institute of Medicine. Rising Above the Gathering Storm, Revisited: Rapidly Approaching Category 5. (National Academy of Sciences, 2010).

21 Jippes, E. Disseminating educational innovations in health care practice: training versus social networks. Social Science \&amp; Medicine (1982) 70, 1509-1517 (2010).

22 Berwick, D. M. Disseminating innovations in health care. JAMA 289, 1969 (2003). 